\title{
ANALYSIS OF SITUATIONAL ORGANIZATION AND LEADERSHIP IN THE IMPROVEMENT OF INSTITUTIONAL PERFORMANCE OF STATE UNIVERSITIES WITH PUBLIC SERVICE IN INDONESIA
}

\author{
Jimad Habibullah*, Maarif M. Syamsul, Affandi M. Joko, Sukmawati Anggraini \\ School of Business, Post-graduate Program, Institute Pertanian Bogor, Indonesia \\ *E-mail: habibullah jimad@yahoo.com
}

\begin{abstract}
This research aims to analyze situational organization and leadership in the performance improvement of State University (PTN) with Public Service (BLU) in Indonesia. The analysis was done by using descriptive statistics at three educational institutions based on the area and the PTN ranking of The Research and Technology and Higher Education Ministry (Kemenristekdikti) version in 2015-2017, i.e. Lampung University, Sebelas Maret University, and Gorontalo State University. A sampling collection method used a nonprobability sampling with purposive sampling technique. The research result shows that the transformation of PTN BLU gets a support and gives a positive impact on organizational improvement. However, the transformation has done still limits to the flexibility in financial management. Government and independence are still intervened by the government. Leaders' behavior expected by their follower is an optimist transformational leader behavior about organizational future and believes that the organization's goal can be achieved. Such a leadership expected by PTN BLU is a leader who is able to express an idea clearly and openly to other people to ease a goal achievement. A PTN BLU leader also has to have good academic competence, reflected from the ability to produce quality academic work.
\end{abstract}

\section{KEY WORDS}

Transformation, leadership, performance, autonomy, governance.

The existence of higher education has an essential and strategic role in a country's development. Higher education becomes the center of a development for science and technology as well as innovation development center that determines the progress of civilization and improves a country's competitiveness. Various problems are still appeared in higher education in Indonesia, such as uneven access to get higher education, low gross participation rates (APK), tuition fee which is still high, there are still many lectures who never met a required qualification, a limited research quality and publication quantity, lack of available educational facilities and infrastructure, academic culture which never been built well, and there are still many departments or higher education that are not accredited yet. On the other hand, the community's demand for the quality of higher education is getting higher.

PTN BLU is a transformation of PTN expected to be an Entrepreneurial University. For a university, a transformation is a necessity. Reale and Primeri (2015) proposed a problem appeared in several universities' transformation studies, which is how big it influences on the organization and the institution of the academic profession. Several shifting need to consider in the management of a university, such as collaboration with the government, private or company's research institution. The emergence of Entrepreneurial University concept has produced warm debates about relationship changes between academic filed and a market which causes the limitations of science and business more blurred, especially in relation with the norm and academic science practical (Owen-Smith and Poweli 2001; Vallas and Lee Kleinman 2008; Lam 2015). However, several experts have a different insight and rate it positively, even emphasizing to build a convergence between the academic and industrial world which can create a new model in the scientific development. It was even built threeparty collaboration (triple helix) or more, namely university, government, industry, and society jointly building a productive relationship (Gibbons et al. 1994; Etzkowitz and Leydesdorff 2000). 
The transformation of PTN to PTN BLU gives university change to increase income from the business activity done by a university. An entrepreneurial university is identified to be able to provide a solution from a problem frequently faced by a contemporary university (Pinheiro and Stensaker, 2013). A university transformation with the entrepreneurial university concept causes a change in the management to use a new public management that provides an educational service in a competitive market (Sulkowski, 2016). An organization that facilitates entrepreneurship has a good competitive advantage and performance, eases new financing and gives an alternative to meet socio-economic demand (Bakar and Mahmood, 2014). A university with entrepreneurial university concept is the effect of a university globalization having several functions, among other things, to encourage economic development, utilize collaboration and innovation of interdisciplinary, fulfill the needs of a shareholder, and improve efficiency and transparency (Oinhero and Stenseker, 2013). An entrepreneurial transformation relates to the mission, teaching, and research, and activity of entrepreneurship activity integrated into the environment and internal factor (Guerrero and Urbano, 2012).

The existence of PTN BLU gives an opportunity for PTN to sell product service without highlighting to make profits and in order to run the program is laid on the principle of efficiency and productivity. BLU application is a form of New Public Management (NPM) theory that places government organization unit as an agent of giving service to the society. Flexibility in BLU is an easiness to manage the budget and create opportunities which can be served as an income and directly used to its operational activity. PTN BLU strengthening is encouraged to do so that when it will transform into PTN BH (independent), it actually has an ability and institutional performance which can be proud of.

There are several studies and guidance used by an institution to assess and rank an institutional performance at university. Gaus and Hall (2016) studied the indicator of university performance in Indonesia from the perspective of academics, i.e. the quality of teaching and research. National Accreditation Agency for Higher Education (BAN-PT) determines seven standards in assessing institution performance of university in Indonesia, i.e. Vision, mission, goals and target, and marketing strategy; governance, leadership, management system, and quality guarantee; Student and graduate; Human Resource; Curriculum, learning, and academic situation; Financing, facilities and infrastructure, and information system and research and community service and cooperation. University performance can be assessed from its ability to conduct internalization and include in the world-class university ranking.

Delgado-Márquez et al. (2011) stated internalization from university as an indicator, and this is in accordance with the ranking institution of international university Times Higher Education Supplement (THES) having four criteria with six indicators, namely research quality criteria with two indicators (weight score is 60 percent), teaching quality with one indicator (20 percent), graduate ability to find a job with one indicator (10 percent) and internalization with two indicators (10 percent). Another international ranking institution, which is QS World University ranking, uses a criterion of an indicator and weight score which is almost similar to THES (Huang, 2012). To achieve that kind of performance is needed a leader who is not only able to manage academics activity as a core business of university but also to have a sense of entrepreneurship, which is an ability to create an opportunity and build a network of cooperation in managing and developing institution. For that matter is needed performance indicator of an accountable higher university and can be accepted by all shareholders.

The role of a leader who is able to transform the idea, wants, university's goal to be understood clearly and implemented by internal followers of university and able to ensure external university to cooperate and give support for goal achievement or the realization of vision expected or in other words a leader has to have an ability to improve institutional performance of university. Ulukan (2005) said that a leader has to be able to see and consider a unique characteristic of a university and evaluate a model property before applied. A leader must also develop a method to help another leader or a candidate to understand and manage changes existing around. 
Leadership is an important factor in organizational life. A study with the topic of leadership develops into all types of organization, either aiming at generating profits or not, including a university. A number of theories about leadership grow as the context of organization and situation following. A leadership gives a main influence on the organization performance achievement (Bass 1990; Dubrin 2001; Yukl 2001; Bratton 2005). The success of an organization depends on the leader's ability to adapt and resilience to the environment which always change. A leader can bring an organization to achieve the best performance through the process of transformation and communication. A transformational leader influences his/her followers by developing and communicating a collective vision and inspiring them to exceed the personal interest for the good of team and organization (Groves and LaRocca, 2011). A leader also conducts a transactional behavior by making a changing with the follower. At a transactional leadership, social change-based leader results in an expected performance, while the follower is expected to agree and follow the leader to ignore punishment (Masa'deh et al., 2016; Bass and Riggio, 2006). This research aims at knowing the organizational situation and a leadership in the performance improvement of BLU in Indonesia.

\section{METHODS OF RESEARCH}

The study was conducted at three Indonesian universities representing an area and the Indonesia's Minister of Research, Technology and Higher Education's version of PTN institution ranking of 2015-2017. Those three institutions selected as a sample were Lampung University (western part, ranking 22 in 2015, rank 18 in 2016 and 2017, was in cluster 2 in 2015-2107), Sebelas Maret University (Central area, rank 9 in 2015, rank 12 in 2016 and rank 11 in 2017, was in cluster 1 in 2015-2017) an Gorontalo State University (eastern area, rank 108 in 2015, rank 47 in 2016 and rank 50 in 2017, was in cluster 3 in 2015 and cluster 2 in 2016-2017). A survey will conduct at every institution to the lecturer and educational staff as a material to analyze the organizational situation and PTN BLU leadership.

Primary data was collected by using a survey method, distributing questionnaire arranged to catch respondents' opinion in considering the condition of PTN BLU based on the observation and or practicing that has been felt. Data was collected by distributing sample to 370 respondents. Sampling collection method used was nonprobability sampling and purposive sampling technique. From that total, a respondent participating was 314 persons which mean the response rate of this study was $85.7 \%$. The data that was dissected relate to the respondents' identity, including gender, education, working duration, type of work, and position, leadership, and institutional performance. A measurement scale used was an interval scale. Data analysis was done by using a descriptive statistic.

\section{RESULTS AND DISCUSSION}

A field survey was conducted at three PTN BLU. From 370 questionnaires distributed to respondents, the returned ones were 317 questionnaires and those can be processed were 314 . There are 176 persons (56\%) man respondents and 138 persons (44\%) woman respondent. Respondents who were a lecture amounting to 198 persons (63\%) and the educational staff were 116 persons $(37 \%)$. While based on the age composition, a respondent at the age of $26-30$ years old is 32 persons $(10.2 \%), 31-35$ years old amounting to 38 persons $(12.1 \%), 36-40$ years old amounting to 45 persons $(14.3 \%), 41-45$ years old by 52 persons $(16.6 \%), 46-50$ years old by 60 persons $(19.1 \%), 51-55$ years old amounting to 53 persons (16.9\%), 50-60 years old by 22 persons (7\%) and above 60 years by 12 persons $(3.8 \%)$.

A lecturer respondent having an additional task is 63 persons (32\%), while a functional lecturer is by 135 persons (68\%). An additional task for a lecturer consists of an assistant rector, dean, assistant dean, department head, study program head, and head of technical implementation unit. Educational staff respondents also have a varied assignment 
background, as many as 34 persons (29.4\%) are assigned at rectorate, 43 persons (37\%) are assigned at deanery or faculty administration and the remaining by 39 persons $(33.6 \%)$ are assigned at department and study program.

A respondent based on the educational background is dominated by a master's degree holder by 114 persons (46\%), doctoral degree holder by $74 \%(23.6 \%)$, undergraduate degree holder by 67 persons $(21 \%)$, associate degree holder by 20 persons $(6.4 \%)$ and high school graduate holder by 9 persons (3\%). All lecturers at least hold a master's degree. This is in line with the application of Law Number 14 Year 2005 regarding Teacher and Lecturers that require a minimum education for lecturers are a Master's Degree.

A respondent reception to the transformation obtains full support from the internal circle, most of them (84.7\%) state to agree and strongly agree. A support from the internal circle is an important requirement for the success of transformation. In this context, a leader and academics are a party involved in the internal transformation of a university (Guerrero and Urbano, 2012). A higher average value (91.6\%) is also stated by respondents that this transformation will give a positive impact on organizational improvement. A university which makes transformation commonly conducts a simultaneous change on its structure, strategy, and control mechanism that cause an alteration on its ideology, cultural system and power relations in the organization (De Boer et al., 2007).

PTN BLU concept that should gives flexibility to the financial management is still fully not felt by most of respondent $(83 \%)$ while the remaining state to have provided flexibility in the financing management, even BLU status on higher education is intended to give flexibility in the financing management based on the economics and productivity principle, and the application of a healthy business practice. This also can be caused by a higher education at all countries that truly depend on the financing given by government so that it feels to have an interest to participate in the financing management of higher education.

Good university governance is very universal and generic to apply at every university. Independence principle in the policy determination that is free from various interventions especially from the government is still felt by PTN BLU. A large part of respondents $(86 \%)$ agrees and strongly agrees that PTN BLU has an independence in determining policy and an organization is not government or bureaucratic's hand extension. As with the autonomy of non-academics management, a large part of respondents (88\%) agrees and strongly agrees that autonomy has been run at a university.

The aspect of the organizational human resource becomes the main pillar of PTN BLU in improving the quality of output and institutional competitiveness. Organizational human resource in the higher education represented by lecturers and educational staff has a contribution in achieving organizational goal. A large part of respondents (89\%) agrees and strongly agrees that the human resource has fulfilled the qualification that supports performance. Qualification is a minimum requirement that needs to be improved by the human resource in running the task and function in giving a contribution to the organization.

Challenges and demands to the existence of university in dealing with changes and dynamics that are more strict, both at national, regional and international level. At a national level, the acceleration of change is signed by the development of Information and Communications Technology (ICT) that requires PTN BLU to be more adaptive and flexible in fulfilling the needs and demands especially in generating graduate needed by the business world and industrial world. A large part of respondents (86\%) agrees and strongly agree to anticipate the demands of national need changes.

At the regional and global level, PTN BLU should make a strengthening for the achievement of a world-class university that becomes one of the indicators of Kemenristekdikti's main performance. World Class University does not only imply a concentrated financial investment but also a comprehensive university management transformation in a global context (Yonezawa and Shimmi, 2015). A large part of respondents (95\%) state that PTN BLU needs to get recognition (accreditation and certification) from the global institution, stating that its existence is equal to another university in the global scale. Accreditation and certification conducted by university to get international recognition needs a process of subjective qualification and reputation (Salmi, 2009). Building 
a cooperation network with an institution in the regional and global level becomes an obligation trusted by most of the respondents (91\%). The cooperation will give an impact, not only a human resource strengthening but also an infrastructure for PTN BLU.

Government support as a regulator (decision maker) and facilitator (facilitation provider) are needed by PTN BLU. A large part of respondents (91.6\%) state that Kemenristekdikti gives support to the performance achievement. As with the Finance Ministry, a large part of respondents (89\%) also state to give support to the performance achievement. Local government as the partner of PTN BLU, according to the large part of respondents $(69.2 \%)$, plays a role to give support to the performance achievement. However, a small part of respondents $(47 \%)$ states that coordination among institution has been done well and reinforcing each other in the performance achievement. Synchronization and harmonization to the policy are truly needed, so will be built synergy among institution in giving support and upholding institution in achieving an expected performance.

In order to get an expected leader is needed a qualification which is in accordance with organizational needs. A large part of respondents $(72 \%)$ states that the requirement of a determined leader candidate has been in accordance with the organization needs. Arrangement and formulation of a candidate is determined by the ad-hoc team through referring to several regulations and documents and considering organization needs. In addition, a large part of respondents (90.4\%) also select a candidate from the internal institution circle since believed to more understand the condition and organizational culture that has been built. This is in accordance with Rasmussen (2015) stating that the best leadership in university is when a leader is prepared from the bottom to top, like that conducted by Norwegian University of Science and Technology that choose rector from the internal circle. It is only a small part of respondents $(44.5 \%)$ stating that the candidate from the external institution, including from abroad can bring an update for organization.

PTN BLU leadership behavior of this survey used a transformational leadership theory with four dimensions (Bass and Steidlmeir 1999). Those four dimensions are an ideal influence, inspirational motivation, intellectual stimulation, and individual consideration. In addition is also used Bass' transactional leadership theory (1985) with three dimensions, which is relationship award that depends on the situation, active management with exception and passive management with an exception. Other those two theories, an authentic leadership theory by Walumba et al. (2008) is also used with four dimensions, i.e. selfconsciousness, moral perspective internalization, a balance management of information and a transparent relationship. A transformational leader is a creative leader who is capable of taking a risk calculated and able to build an innovative and satisfying organization (Bakar and Mahmood, 2014; deng, 2017). A transformational leadership involves and inspires its follower to commit to the vision and a joint goal of an organization or unit, challenges them to be an innovative problem breaker and develops followers' ability through a coaching, accompaniment, and a provision, both support and challenge (Bass and Riggio, 2006).

Respondents' expectation on PTN BLU leader behavior at the dimension of ideal influence is reflected from the average answer of the survey. The biggest average is at the leader's behavior that emphasizes the importance of having organizational's collective mission and a great goal that becomes a spirit for organization member. At the dimension of inspirational motivation, the biggest average score is at the leader's behavior to always talk optimistically about the organization's future and the behavior to disclose the truth that the goal will be achieved. The result at the dimension of intellectual stimulation shows that the biggest average score suggests a new method in the finishing task. Task finishing with a new method enables employee to be spared from boredom and makes them able to finish task more effectively. At the dimension of individual consideration, the biggest average is on the behavior that continuously has different needs, ability, and aspiration from others. A leader understands his/her followers need and act as a mentor or trainer for his/her follower, and listens to the concern and the needs of his/her follower (Judge and Picolo, 2004). An understanding of followers' needs can increase working satisfaction (Bryman, 2007).

Transactional leadership is a leader behavior that uses an exchange or transaction to influence and direct the follower in increasing contribution for organization's goal 
achievement. This kind of leadership depends on the contract or a reciprocal relationship between the leader and subordinate (Vito et al, 2014; Jung and Avolio, 2000).

The result of a survey on the transactional leadership behavior at the dimension of related awards that depends on the situation, the highest score is on the behavior of giving a gift to other as a return of their effort and the behavior shows satisfaction when other people meet the expectation. At the dimension of management based on an active exception, the biggest average score is a behavior that centralizes concern on the failure management and a behavior that directs concern on the failure to fulfill the standard. At the last dimension of transactional behavior, which is a management based on the passive exception, the biggest average score from the respondent at the failure behavior anticipates until the problem becomes serious and the behavior waits for the wrong something before taking an action. A leader who uses a management of active exception will monitor the follower performance and take a correlative action, while a leader with a management of active exception enables the quo status and will only conduct intervention when a problem has been so serious (Deng, 2017).

If being compared, the average value of transactional leadership behavior is still smaller than the average value of transformational leadership. For that matter, the respondent will more choose or want a transformational leadership for PTN BLU leader. This matter can be understood because a transformational leader gives an example, tries to inspire and motivates subordinate to achieve the goal and works beyond expected by the organization. The understanding of the needs of subordinates also makes them feel honored and cared for by the leader. Leaders can use transactional leadership to achieve the expected goals; they can also use transformational leadership to achieve higher goals, which require changes in attitudes, abilities, and beliefs of followers (Deng, 2017).

An authentic leadership is a pattern of leadership behavior that uses and supports psychological capacity and a positive ethical climate to strengthen self-understanding, moral perspective, balanced information processing, and transparency of the relationship between leaders and followers to strengthen a positive self-development (Walumba et al, 2008).

The survey results on authentic leadership behavior and the dimension of selfawareness, the highest average value is on the behavior clearly realizing its influence on others and behavior to ask for feedback to improve relationships with others. In a transparent relationship dimension, the highest average value is a behavior expressing an idea and thought clearly to others and openly sharing information with others. Submitting ideas clearly and openly makes other people able to carry out tasks well and facilitate the achievement of organizational goals. In the dimension of internalizing the moral perspective, the highest average value is behavior that shows consistency between beliefs and actions and behaviors carried out guided actions based on internal moral standards. Authentic leaders can understand themselves better through a reflection of self-introspection about values, identity, emotions, and motives and goals (Larson and Eid, 2012). In the final dimension of authentic leadership behavior, which is a balanced information processing, the highest average value is the behavior of analyzing relevant data objectively before making decisions and behavior to listen carefully to alternative perspectives before reaching a conclusion.

The competency model is very useful in order to identify the knowledge, skills, and behavior needed in order to develop leadership and achieve the organization's strategic goals (Spendlove, 2007; Naquin and Holton, 2006). In this study, leader competencies are grouped into four categories, namely academic competencies, business competencies, managerial competencies, and ethical competencies. As a leader of academic institutions, a leader must certainly have academic competence. Academic competence is seen from the ability of PTN BLU leaders to produce quality academic works. In addition is the ability to build a dynamic academic culture and the ability to carry out academic quality assurance on an ongoing basis. These three academic competencies obtain very high average scores from respondents.

Business competency is needed by the leaders of PTN BLU in increasing the value and income of the institutions used in providing services to stakeholders. Business competency is seen from the ability of PTN BLU leaders in understanding the institutional 
business context by providing solutions to the problems faced. In addition, the ability of entrepreneurship in creating innovations that generates income for the institution. Another business competency is the ability to build a network of cooperation, especially with the business world or industrial world that provides mutual benefits.

Managerial competencies relate to the managerial activities in designing, implementing and evaluating activities that can support performance. Managerial competence of this study consists of decision-making ability in implementing organizational strategic plans, the ability to design organizations that are adaptive to the dynamics of changes in the organizational environment, the ability to build communication in the context of coordination to ensure commitment in achieving the goals and ability to solve problems by providing learning in each organizational level. Respondents also gave high average scores on managerial competence.

Ethical competence includes the aspects of value management, development and moral reasoning, public and personal morality and ethical skills. The ethical competence is related to the ability to manage organizational values as a basis for organizational practice, moral reasoning ability as a basis for ethical decision making in policy setting, the ability to understand ethics as a means of dealing with organizational conflicts and the ability to reject behavior that is contrary to ethics.

The regeneration process of the PTN BLU leadership is held once every four years, as a period of leadership. Regulations allow the PTN BLU leader to continue for one return period while still meeting the requirements related to age. A large part of respondents $(89 \%)$ stated that there must be a willingness to share experiences with the leaders who replaced them. Sometimes, there is reluctance from the successor of the leadership to continue the policies or programs that have been implemented by the predecessor, even though the policy or program is quite good. Therefore, it frequently hears the term "changing the leader means changing the policy".

The existence of gaps in building relationships between old leaders and their successors allows the absence of sustainability of policies or programs that have been carried out in the previous period. Most of respondents (88\%) agreed and strongly agreed that there was a need for continuity or sustainability of policies or programs that would benefit the achievement of institutional performance. Every period of leadership is expected to have a legacy (inheritance) which is a milestone for the progress of each period. This legacy should be in harmony with the road map which has been compiled in the long term as a continuous organizational performance.

The performance of PTN BLU can be measured from the achievement of academic performance and financial performance. Academic performance uses standards determined by Kemenristekdikti. While the financial performance use the standards determined by the Ministry of Finance. As an academic institution, academic performance should be the main measure, while financial performance is more like a supporter (supporting) for academic performance achievement. In addition to using the measures set by the Ministry of Research, Technology and Higher Education, the academic performance can also use the standards used by global accreditation institutions and global university rating agencies. Academic performance standards frequently used by the Ministry of Research and Technology are accreditation issued by BAN-PT, both for study programs and at the institutional level. Accreditation assessment standards use seven standards, which assess academic aspects that consist of the implementation of the three pillars of higher education and non-academic aspects as supporting consisting of facilities, financial human resources, and information systems. Respondents stating that academic performance are in line with the Kemristekdikti target is $79 \%$. The financial performance standards used by the finance ministry use indicators of financial aspects and service aspects. Financial aspects are assessed from the analysis of financial statements in the form of financial ratios and compliance with the BLU PK regulations. Service aspects are assessed based on the quality of services provided and benefits to the community (including the customer satisfaction index).

Institutional performance achievement will have an impact on the satisfaction of all members of the organization. Organizational member satisfaction will give rise to increased 
commitment and contribution in the future. Respondents stating that all members of the organization were satisfied with the institution's performance are $59 \%$. There is still the potential to increase satisfaction by increasing performance. Whereas $82 \%$ of respondents stating that all members of the organization are ready to contribute to support the achievement of better institutional performance and realize a world-class university.

\section{CONCLUSION AND SUGGESTIONS}

The transformation of a university into PTN BLU gets internal support and is felt to have a positive impact on the progress of the organization. However, the transformation carried out is felt not to provide flexibility in the financial management of PTN BLU. In terms of PTN BLU governance, the independence is principally felt to be not maximal especially in terms of autonomy and policy setting without government intervention. In carrying out the transformation, the human resources of PTN BLU have fulfilled the qualifications, competence, motivation, and integrity that support performance. PTN BLU seeks adaptive to face the demands of change at the local, regional and international levels and to strengthen the achievement of world-class universities. Government support is also needed in achieving the performance of PTN BLU.

To meet the needs of PTN BLU, the leader of PTN BLU was chosen from internal institutions, because it was believed to better understand the conditions and culture of the organization that had been built. The leader's behavior of PTN BLU can be transformational or transactional, but the behavior desired by followers is the behavior of transformational leaders who are optimistic about the future of the organization and have confidence that organizational goals can be achieved. The leaders' authenticity expected in PTN BLU is leaders who are able to convey ideas clearly and openly to others to facilitate the achievement of goals. A PTN BLU leader also has to have good academic competence, reflected from the ability to produce quality academic work.

In the leader's regeneration process, policy sustainability is expected to achieve the performance set by the PTN BLU. The performance of PTN BLU can be measured by academic performance and financial performance. Academic performance is the main measure directed at achieving a world class university, while financial performance is a supporting performance in achieving academic performance.

The results of the study indicate that the process of transforming universities into PTN BLU in Indonesia has not gone well. Synergy from various related institutions is needed in order to maximize the management of PTN BLU in order to achieve the best performance by providing flexibility in financial management and autonomy in carrying out university governance, the process of recruiting leaders who are free of intervention and various competencies is also needed so that PTN BLU can develop into an entrepreneurial university which is able to provide the best academic performance.

\section{REFERENCES}

1. Bakar, M.S., Mahmood, R. (2014). Linking Transformational Leadership and Corporate Entrepreneurship To Performance In The Public Higher Education Institutions In Malaysia. Advances in Management \& Applied Economics, 4 (3), 109-122.

2. .Bass, B. M. 1985. Leadership and performance beyond expectations. New York: Free Press.

3. 1990. From Transactional to Transformational Leadership: Learning to Share the Vision. Organizational Dynamics. 18(3), 19-31.

4. Bass, B.M., \& Riggio, R.E. (2006). Transformational Leadership. Second Edition. New Jersey London.: Lawrence Erlbaum Associates.

5. Bass, B.M., Steidlmeier, P. (1999). Ethics, Character, And Authentic Transformational Leadership Behavior. Leadership Quarterly,10 (2), 181 - 217.

6. Bratton, J., Grint, K. dan Nelson, D. L. 2005. Organizational Leadership. Mason, Ohio: Thomson Southwestern. 
7. Bryman, A. (2007). Effective Leadership In Higher Education: A Literature Review. Studies In Higher Education. 32 ( 6). 693-710.

8. De Boer, H.F., Enders, J., \& Leisyte, L. 2007. Public Sector Reform In Dutch Higher Education: The Organizational Transformation Of The University. Public Administration. 85 (1), $27-46$.

9. Delgado-Marquez, B.L., Hurtado-Torres, N.E., \& Bondar, Y. 2011. Internationalization of Higher Education: Theoritical and Empirical Investigation of Its Influence on University Institution Rankings. Revista de Universidad y Sociedad del Conocimiento, 8 (2), 265284.

10. Deng, J. (2017). Leadership In Education Abroad Office: A Case Study Based On The Interactional Framework Of Leadership And The Transformational - Transactional Leadership Theory. Dissertation. Binghamton University State University Of New York. Published By Proquest LLC.

11. Dubrin, A. J. 2001. Leadership - Research Findings, Practice, and Skills, 3rd edition. Boston: Houghton Mifflin Company.

12. Etzkowitz, H., \& Leydesdorff, L. (2000). The Dynamics of Innovation: From National Systems and 'Mode 2' to a Triple Helix of University-Industry-Government Relations. Research Policy, 29(2), 109-123.

13. Gaus, N., \& Hall, D. 2016. Performance Indicators in Indonesian Universities: The Perception of Academics. Higher Education Quarterly. 70(2), 127-144.

14. Gibbons, M., Limoges, C., Notwotny, H., Schwartzman, S., Scott, P., \& Trow, M. (1994). The New Production of Knowledge. London, UK: Sage.

15. Groves, K.S., \& LaRocca, M.A. 2011. An Empirical Study of Leader Ethical Values, Transformational and Transactional Leadership, and Follower Attitudes Toward Corporate Social Responsibility. Journal of Business Ethics. 103(4), 511-528.

16. Guerrero, M., \& Urbano, D. (2012). The development of an entrepreneurial university. The Journal of Technology Transfer. 37 (1). 43-74.

17. Huang, M-H. 2012. Opening The Black Box Of QS World University Rankings. Research Evaluation. 21(1), 71-78.

18. Judge, T.A., \& Piccolo, R.F. (2004). Transformational and Transactional Leadership: A Meta-Analytic Test of Their Relative Validity. Journal of Applied Psychology. 89 (5), 755768.

19. Jung, D.I., \&; Avolio, B. J. (2000). Opening The Black Box: An Experimental Investigation Of The Mediating Efects Of Trust And Value Congruence On Transformational And Transactional Leadership. Journal Of Organizational Behaviour. 21, 949- 964.

20. Larsson, G., \& Eid, J. (2012). An Idea Paper On Leadership Theory Integration. Management Research Review. 35 (3/4), 177-191.

21. Masa'deh, R, Obeidat, \& B.Y., Tarhini, A. (2016). A Jordanian Empirical Study Of The Associations Among Transformational Leadership, Transactional Leadership, Knowledge Sharing, Job Performance, And Firm Performance: A Structural Equation Modelling Approach. Journal of Management Development. 35 (5), 681-705.

22. Naquin, S.S., \& Holton, E.F. (2006). Leadership and Managerial Competency Models: A Simplified Process and Resulting Model. Advances in Developing Human Resources. 8 (2), 144-165.

23. Owen-Smith, J. ; Powell, W. (2001). Careers And Contradictions: Faculty Responses To The Transformation Of Knowledge And Its Uses In The Life Sciences. Research in the Sociology of Work, 10, 109-140

24. Pinheiro, R., \& Stensaker, B. (2013). Designing the Entrepreneurial University: The Interpretation of a Global Idea. Public Organization Review. 14 (4), 497-516.

25. Rasmussen, Bente. (2015). From Collegial Organization to Strategic Management of Resources: Changes in Recruitment in a Norwegian University. Sage Open. 1-11.

26. Reale Emanuela; Primeri, Emilia (Eds). 2015. The Transformation of University Institutional and Organizational Bopundaries. Higher Education Research in the 21st Century Series Volume 8. Sense Publishers 
27. Salmi, J. (2009). The Challenge of Establishing World-Class Universities. Washington: The International Bank for Reconstruction and Development / The World Bank.

28. Spendlove, M. (2007). Competencies For Effective Leadership In Higher Education. International Journal of Educational Management. 21 (5), 407-417.

29. Sułkowski, Ł. (2016). Accountability of University: Transition of Public Higher Education. Entrepreneurial Business and Economics Review. 4.(1), 9-21.

30. Ulukan, C. 2005 Transformation of University Organizations: Leadership and Managerial Implications Turkish Online Journal of Distance Education-TOJDE October 2005 ISSN 1302-6488 Volume: 6 Number: 4 Article: 8

31. Vallas, S. P. Kleinman, D. L. (2008). Contradiction, Convergence And The Knowledge Economy: The Confluence Of Academic And Commercial Biotechnology. SocioEconomic Review, 6(2), 283-311.

32. Vito, G.F., Higgins, G.E., \& Denney, A.S. (2014). Transactional And Transformational Leadership: An Examination Of The Leadership Challenge Model. Policing: An International Journal of Police Strategies \& Management. 37 (4), 809-822.

33. Walumbwa, F.O., Avolio, B. J., Gardner, W.L., Wernsing, T.S., \& Peterson, S. J. (2008). Authentic Leadership: Development and Validation of a Theory-Based Measure. Journal of Management. 34 (1), 89-126.

34. Yonezawa, A., \& Shimmi, Y. (2015). Transformation Of University Governance Through Internationalization: Challenges For Top Universities And Government Policies In Japan. Higher Education. 70 (2), 173-186.

35. Yukl, G. 2001. Leadership in Organization. Fifth Edition. Prentice Hall.Inc. 